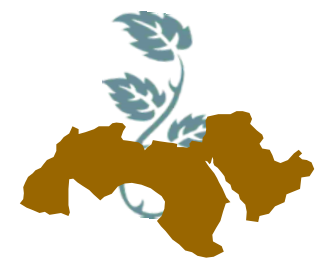

\title{
ENHANCEMENT OF SALT TOLERANCE IN WATERMELON USING GRAFTING
}

\author{
Asmaa, A.A. Sharf-Eldin; Amal M. El-Shraiy; M.A.M. Eisssa \\ and Sanaa A.M. Zaghlool \\ Agric. Botany Dept. Fac. of Agric., Ain Shams Univ., Cairo, Egypt
}

Keywords: Watermelon, salt stress, grafting, rootstock; Cucurbita maxima x C. moschata, membrane permeability, salt injury index

\section{ABSTRACT}

Pots experiment was conducted in the experimental farm of Agricultural Botany Department, Faculty of Agriculture, Ain Shams Univ. during the seasons of 2015 and 2016 to investigate the effect of grafting on salt tolerance of watermelon plants. Watermelon (Citrullus lanatus, Hybrid F1) Aswan1 was grafted onto the rootstock of Flexifort pumpkin (Cucurbita maxima x C. moschata) and irrigated with four different concentrations of $\mathrm{NaCl}$ (0.0, 2000, 4000, 6000 ppm). Two samples were taken at 20 and 40 days after planting (DAP). Plant height, leaf numbers and area, branches number, root length, and shoot and root fresh and dry weights were negitavly affected by salinity in ungrafted plants and this effect was directly proportional to $\mathrm{NaCl}$ concentrations. On the contrary, grafting positively affected the aforementioned parameters and minimized the harmful effect of salinity. Furthermore, grafted plants showed higher growth vigor comparing with ungrafted control plants or plants received the same treatment of $\mathrm{NaCl}$ and these effects were mostly siginificant. An increase in membrane permeability (MP) was detected at 20 and 40 DAP by application of different levels of $\mathrm{NaCl}$ salinity and this effect was positively correlated with $\mathrm{NaCl}$ concentration. Grafted plants showed decreasing in MP with $12.7 \%$ higher LRWC than ungrafted plants. Under 2000, 4000, $6000 \mathrm{NaCl}$ ppm salinity levels, the values of salt injury index recorded 15.1, 26.5 and 37.5 in ungrafted plants at 20 DAP comparing with $0.0,6.9$ and 12.9 in grafted ones.

\section{INTRODUCTION}

Approximately $20 \%$ of the world's cultivated land and nearly half of all irrigated lands are affected by salinity (Zhu, 2001). Salinity in irrigation water and in soils is one of the major abiotic constraints on agriculture worldwide, and the situation has worsened over the last 20 years due to the increase in irrigation requirements in arid and semi-arid regions such as those found in the Mediterranean area (Munns and Gilliham, 2015 and Cirillo et al 2016).

Salt stress changes the plant's morphological and physiological traits and biochemical responses (Sevengor et al 2011 and Kusvuran et al 2013). The initial and primary effect of salinity is due to its osmotic effect, leading to low water potential of the root medium. Two other effects of salinity are toxicity of ions, mainly $\mathrm{Na}^{+}$and $\mathrm{Cl}^{-}$, and nutrient imbalance due to a decrease in uptake and/or transport during plant growth (Jacoby, 1994; Marschner, 1995 and Levitt 1980). Therefore, salt resistance often depends on the ability of the plant to develop adaptive strategies under stress conditions (Ors and Suarez, 2016). To alleviate these problems, grafting is recommended as an important technique for vegetable production in many countries where intensive and continuous cultivation is performed.

Grafting is used in watermelon production to improve the salinity tolerance of plants (Yetisir and Uygur , 2010), to enhance nutrient absorption (Ruiz et al 1997), to improve water use (Cohen and Naor 2002), to control Fusarium wilt, to increase low temperature tolerance, and to increase yield by enhancing water and plant nutrient uptake (Lee, 1994 and Oda, 1995). Cucurbit plants are grafted onto various rootstock species and varie- 
ties using a range of grafting methods and commonly include watermelon, melon and cucumber. The most common rootstocks for watermelon are bottle gourd, interspecific hybrids between $C$. maxima and C.moschata and wild watermelon (C. lanatus var. citroides) (Davis et al 2008 and Karaağaç \& Balkaya, 2013). Grafting onto salttolerant rootstock is an active method for increasing the salt tolerance of plants. Grafting has been found to improve the salt tolerance in several vegetable crops such as; tomato (Estan et al 2005), eggplant (Curuk et al 2009), watermelon (Yetisir and Uygur, 2010), melon (Dasgan et al 2015), and cucumber (El-Shraiy et al 2011). Grafting can raise the salt tolerance of watermelon and melon (Yetisir \& Uygur, 2010 and Dasgan et al 2015).

Watermelon was grafted onto Cucurbita moschata, C. maxima, Benincasa hispida, and Lagenaria siceraria. L. siceraria a species widely used as rootstock for watermelon (Lee, 1994).

Therefore, the present study was conducted to investigate the enhancement effect of grafting using Flexifort pumpkin (Cucurbita maxima $\times$ C. moschata) as rootstock on improving salt tolerance in watermelon plants. In this respect, plant growth vigor, leaves relative water content, membrane permeability (electrolyte leakage) and salt injury index were investigated.

\section{MATERIALS AND METHODS}

\section{Plant materials}

Pots experiment was performed in a greenhouse of the Agricultural Botany Department, Faculty of Agriculture, Ain Shams University, at Shoubra El-Kheima, Kalubia, Egypt, during the seasons of 2015 and 2016. Watermelon Hybrid F1 (Citrullus lanatus) Aswan 1 was used as a scion and Flexifort pumpkin (Cucurbita maxima $\mathrm{x} C$. moschata) was used as rootstock. Flexifort was selected as the most representative commercial rootstock used in Egypt due to its high compatibility with watermelon cultivars and its resistance to soil borne pathogens. Flexifort pumpkin seeds were sown in greenhouse on $1^{\text {st }}$ January in foam trays (84 cells) filled with mixture of peat: vermiculite $(3: 1, v: v)$. Three days later, seeds of watermelon scion were sown. Plants were ready for grafting when seedlings of the rootstock had developed two cotyledon leaves (after 14 day from sowing), the watermelon seedling with one true leaf was grafted onto the rootstock. Using the pro- cedure of the "one cotyledon graft" is also known as "splice" grafting (Cushman, 2006 and Oda, 1995) as shown in diagram (1). The seedlings were incubated for 5 days on $24-26^{\circ} \mathrm{C}$ air temperature, relative humidity of $95 \%$ and $30-50 \%$ shading under plastic tunnel in the nursery. Ten days after grafting (5 days after incubation), plants were transferred to the greenhouse where grafted and ungrafted plants were transplanted into plastic pots (20 kg capacity) filled with washed sandy soil (2 plants / pot) and thinned to one plant at seven days after sowing.

\section{Treatments}

The experiment was designed as a factorial combination of the following:

a. Two grafting treatments; ungrafted and grafted watermelon. Ungrafted watermelon plants and watermelon scions plants were sown at the same date.

b. Four salinity treatments; o, 2000, 4000 and $6000 \mathrm{ppm} \mathrm{NaCl}$. Salinity treatments were established by adding (0, 2000, 4000, 6000 ppm) $\mathrm{NaCl}$ to a base complete nutrient solution (Hoagland nutrient solution was prepared according to Kong et al (2005). Plants were irrigated by the solution every 5 days during the growing period.

Pots were arranged in a piece of splinter once design with three replicates (3pots/ treatment/ replicate).

\section{Growth measurements}

Samples were taken at 20 and 40 days after planting (DAP) for growth measurements; main stem height $(\mathrm{cm})$, leaf area $(\mathrm{cm})^{2}$, number of leaves, number of lateral shoot. Root length $(\mathrm{cm})$, root and shoot fresh and dry weights $(\mathrm{g})$ were recorded at 40 DAP. A known weight of plants were dried in a ventilated oven at $70^{\circ} \mathrm{C}$ for $24 \mathrm{~h}$, then at $105^{\circ} \mathrm{C}$ for $3 \mathrm{~h}$. Plants dry weight was determined and expressed as g. dry weight / plant. The leaf area (LA) of second fully expanded leaves of grafted and non-grafted watermelon plants were estimated using the equation $\mathrm{LA}=2.99+0.50 \mathrm{LW}$ according to Rouphael et al (2010) as shown in Figure (1).

\section{Measurement of membrane permeability}

For measurement of MP, 20 leaf discs $(10 \mathrm{~mm}$ in diameter) from the young fully expanded leaves 
were placed in $50 \mathrm{ml}$ glass vials, rinsed with distilled water to remove electrolytes released during leaf disc excision. Vials were then filled with $30 \mathrm{ml}$ of distilled water and allowed to stand in the dark for $24 \mathrm{~h}$ at room temperature. Electrical conductivity $(E C 1)$ of the bathing solution was determined at the end of incubation period. Vials were heated in a temperature-controlled water bath at $95^{\circ} \mathrm{C}$ for 20 min, and then cooled to room temperature and the electrical conductivity (EC2) was measured. Electrolyte leakage was calculated as percentage of EC1/EC2 (Shi et al 2006).
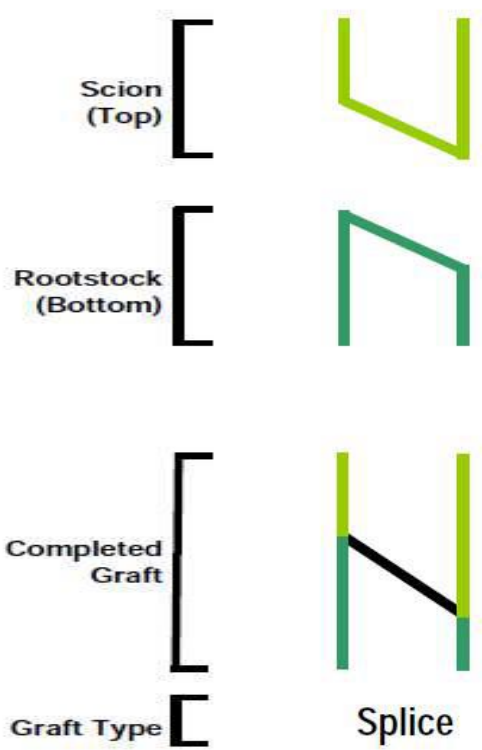

Fig .1. Diagram of Splice grafting after Lee (2003)

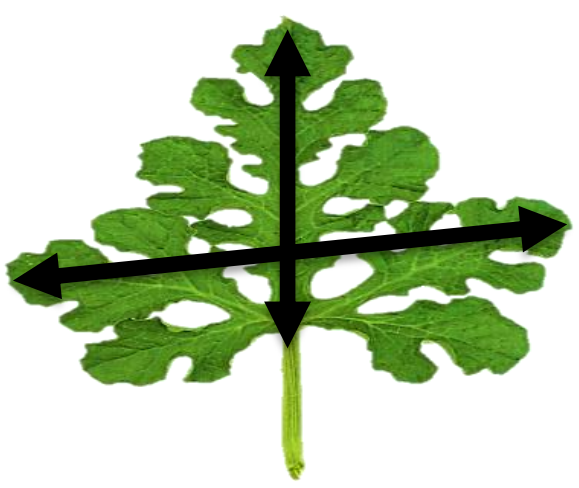

Figure 2. The leaf area (LA) of watermelon were estimated using the equation $\mathrm{LA}=2.99$ $+0.50 \mathrm{LW}$

\section{Determination of leaf relative water content (LRWC)}

The second fully expanded youngest leaf from top was taken and four leaf discs ( $1.0 \mathrm{~cm}$ diameter) of each leaf were sampled and immediately weighed fresh weight (FW). Then, they were immersed in distilled water in Petri dishes for $24 \mathrm{~h}$ at $4{ }^{\circ} \mathrm{C}$ in darkness and the turgid weight (TW) determined. The discs were dried in an oven at $70{ }^{\circ} \mathrm{C}$ for $24 \mathrm{~h}$ and the dry weight (DW) obtained. Then RWC was calculated as given below according to the method of (Silveira et al 2003):

$R W C(\%)=F W-D W / T W-D W * 100$

\section{Salt injury index}

Plants grown for $20 \& 40$ days under different $\mathrm{NaCl}$-salinity levels were classified for their salt tolerance by visual appearance following the method of Zhang et al (2003). The classified criteria of salt injury are: 0 level (non-sufferable injury), 1 level (one-third of the leaf edge suffered injury), 2 level (two-thirds of the leaf edge suffered injury), 3 level (full leaf edge suffered injury or one-third of the lamina desquamated), 4 level (two-thirds of the lamina desquamated), 5 level (full lamina desquamated). The salt injury index was calculated by using the equation:

salt injury index $(\%)=\Sigma$ (level value $\times$ plant number $) \times$ $100 /$ (the highest level value $\times$ total plant number).

\section{Statistical analysis}

Data were statistically analyzed using CoStat software (version 6.4, CoHort Software, USA) according to the method described by Gomez and Gomez (1984). One way (ANOVA) were used to test for significant differences among treatments. Significance between means was tested by Tukey's student zed range test at the $5 \%$.

\section{RESULTS AND DISCUSSION}

The following results represent the mean of the two seasons

\section{Growth parameters}

As shown in Tables (1 and 2), growth parameters at 20 and 40 DAP; plant height, leaf numbers and area, branches number was negatively affected by salinity and this effect was proportional to 
Table 1. Effect of different levels of $\mathrm{NaCl}$ salinity on some growth parameters of ungrafted (UG) and grafted $(G)$ watermelon plants at 20 days after planting

\begin{tabular}{|c|c|c|c|c|}
\hline Treatments & $\begin{array}{l}\text { Plant } \\
\text { height } \\
\text { (cm) }\end{array}$ & $\begin{array}{c}\text { Leaf } \\
\text { numbers }\end{array}$ & $\begin{array}{c}\text { Leaf area } \\
\left(\mathrm{cm}^{2}\right)\end{array}$ & $\begin{array}{c}\text { Branches } \\
\text { number }\end{array}$ \\
\hline UG & $32.0 \mathrm{c}$ & $5.1 \mathrm{ab}$ & $38.6 \mathrm{bc}$ & 2.3ab \\
\hline $\mathrm{G}$ & $38.3 a$ & $5.53 a$ & $44.0 \mathrm{a}$ & $2.6 \mathrm{a}$ \\
\hline$U G+2000$ ppm & & & $286 \mathrm{~d}$ & $20 \mathrm{~h}$ \\
\hline $\mathrm{NaCl}$ & $26.0 d$ & $5.3 a$ & $28.6 a$ & $2.0 \mathrm{~b}$ \\
\hline $\begin{array}{l}\mathrm{UG}+4000 \\
\mathrm{ppm} \mathrm{NaCl}\end{array}$ & $19.7 f$ & $3.6 c$ & $14.6 \mathrm{e}$ & $1.0 \mathrm{c}$ \\
\hline$U G+6000$ & & & 1160 & \\
\hline ppm $\mathrm{NaCl}$ & $16.3 \mathrm{~g}$ & $2.7 d$ & $14.6 \mathrm{e}$ & $0.01 \mathrm{c}$ \\
\hline$G+2000 p p m$ & & & $416 a b$ & $230 \mathrm{~h}$ \\
\hline $\mathrm{NaCl}$ & $36.33 b$ & $5.4 a$ & $41.6 a b$ & 2.3ab \\
\hline $\begin{array}{c}\mathrm{G}+4000 \mathrm{ppm} \\
\mathrm{NaCl}\end{array}$ & $33.0 \mathrm{c}$ & $4.3 b c$ & $37.6 \mathrm{c}$ & $2.0 \mathrm{~b}$ \\
\hline $\begin{array}{l}\mathrm{G}+6000 \\
\mathrm{ppmNaCl}\end{array}$ & $23.0 \mathrm{e}$ & $3.8 \mathrm{c}$ & $26.3 d$ & $1.0 \mathrm{c}$ \\
\hline LSD & 1.7 & 0.81 & 3.7 & 0.64 \\
\hline
\end{tabular}

$\mathrm{NaCl}$ concentrations. On the contrary, grafting increased the aforementioned parameters and minimized the harmful effect of salinity. Furthermore, grafted plants showed higher growth vigor comparing with ungrafted control plants either under zero salinity or 2000 to $6000 \mathrm{ppm}$ salinity. Plant height at 20 \& 40 DAP recoded 38.3 and $82.3 \mathrm{~cm}$ in grafted plants comparing to 32.0 and 62.0 in ungrafted ones.

Significant reduction in shoot and root fresh and dry weights was detected parallel to increasing $\mathrm{NaCl}$ levels, the highest reduction was recorded by 6000 ppm NaCl. Grafting showed obvious improvement in these parameters. The mean values of shoot and root fresh weights were $59.9,15.2 \mathrm{~g}$ in grafted plants comparing with $44.4,11.3 \mathrm{~g}$ for ungrafted ones. Moreover, under different levels of salinity grafting enhanced also root length.

Reduction in growth in response to salinity is usually attributed to either ion toxicity or low external osmotic potential (Munns and Termatt, 1986). Inhibition of plant growth by salinity is the result of low osmotic potential of soil (water stress), nutritional imbalance, specifc ion effect (salt stress) or a combination of these factors (Parvaiz and Satyawati, 2008). Salt-tolerant plants differ from saltsensitive ones in having a low rate of $\mathrm{Na}^{+}$and $\mathrm{Cl}^{-}$ transport to leaves, and the ability to compartmentalize these ions in vacuoles to prevent their build-up in cytoplasm or cell walls and thus avoid salt toxicity( Munns, 2002).

\section{Membrane permeability (MP)}

An increase in membrane permeability (MP) was detected at 20 and 40 DAP under $\mathrm{NaCl}$ salinity (Tables 3 and 4 ) and this effect was correlated with $\mathrm{NaCl}$ salinity concentration. The maximum values of MP were observed with 6000ppm $\mathrm{NaCl}$. Grafting reduced this harmful effect of salinity by decreasing MP. The best values of MP were observed with zero $\mathrm{NaCl}$ salinity of ungrafted and grafted plants.

Membrane permeability is a sensitive test to determine salt stress and tolerance (Mansour and Salama , 2004). Cell membrane stability has been widely used to differentiate stress tolerant and susceptible cultivars of some crops. Kaya et al (2001) suggested that, increase in membrane permeability at seedling stage were lower than at vegetative stage at high salinity and this also shows a strong link between time of exposure to high salinity and membrane permeability. Zhu et al (2008) mentioned that membrane permeability significantly increased with salt stress for salttolerant cultivar. Similar results were observed on mulberry (Sudhakar et al 2001), tomato (Alpaslan and Gunes, 2001), cotton (Meloni et al 2003) and Catharanthus roseus (Elkahoui et al 2005).

\section{Leaf relative water content (LRWC)}

Data in (Tables 3 and 4) reveal that different levels of $\mathrm{NaCl}$ salinity significantly decreased leaf relative water content (LRWC). The highest reduction of LRWC at 20 DAP was $26.0 \%$ in ungrafted plants under $6000 \mathrm{ppm} \mathrm{NaCl}$ salinity. On contrary grafted plants recorded $12.7 \%$ an increase in LRWC. Grafted plants under saline condition showed significant increase in LRWC comparing with ungrafted plants received the same concentrations of $\mathrm{NaCl}$.

Water status in plant under salt stress is the most limiting factor affecting plant growth. Maintain relative water content under existing $\mathrm{NaCl}$ stress allow to resume growth (Yeo et al 1985 and Munns \& Tester, 2008). Therefore, higher concentration of $\mathrm{Na}^{+}$and $\mathrm{Cl}^{-}$are often detrimental to salt-sensitive plants. On the contrary, showed salinity-tolerant plants as well as salt tolerant root stocks accumulating of several organic osmolytes, especially organic compatible solutes, in response to osmotic stress. The primary function of compatible solutes is to maintain cell turgor and to uptake more water from the soil. Compatible solutes was found to be in three major catogeries: amino acids 
Table 2. Effect of different levels of $\mathrm{NaCl}$ salinity on some growth parameters of Ungrafted (UG) and grafted $(G)$ watermelon plants at 40 days after planting.

\begin{tabular}{|c|c|c|c|c|c|c|c|c|c|}
\hline Treatments & $\begin{array}{c}\text { Plant } \\
\text { height } \\
(\mathrm{cm}) \\
\end{array}$ & $\begin{array}{c}\text { Leaf } \\
\text { numbers }\end{array}$ & $\begin{array}{c}\text { Leaf area } \\
(\mathrm{cm} 2)\end{array}$ & $\begin{array}{c}\text { Branches } \\
\text { number }\end{array}$ & $\begin{array}{c}\text { Shoot } \\
\text { fresh } \\
\text { weight (g) }\end{array}$ & $\begin{array}{l}\text { Shoot dry } \\
\text { weight (g) }\end{array}$ & $\begin{array}{c}\text { Root } \\
\text { fresh } \\
\text { weight }(\mathrm{g}) \\
\end{array}$ & $\begin{array}{l}\text { Root dry } \\
\text { weight }(\mathrm{g})\end{array}$ & $\begin{array}{l}\text { Root } \\
\text { length } \\
(\mathrm{cm}) \\
\end{array}$ \\
\hline UG & $62.0 \mathrm{c}$ & $6.0 a b$ & $73.0 \mathrm{~b}$ & $3.0 \mathrm{~b}$ & $44.4 d$ & $9.2 b$ & $11.3 \mathrm{c}$ & $6.2 \mathrm{c}$ & $21.3 c$ \\
\hline G & $82.3 a$ & $6.7 a$ & $91.0 \mathrm{a}$ & $4.0 \mathrm{a}$ & $59.9 a$ & $10.6 a$ & $15.2 \mathrm{a}$ & $8.6 a$ & $27.7 a$ \\
\hline $\begin{array}{c}\mathrm{UG}+2000 p p m \\
\mathrm{NaCl}\end{array}$ & $49.6 d$ & $5.6 a b c$ & $48.3 c$ & $2.3 \mathrm{c}$ & $33.2 \mathrm{e}$ & $7.3 \mathrm{c}$ & $8.8 d$ & $5.3 d$ & $16.9 \mathrm{e}$ \\
\hline $\begin{array}{l}\mathrm{UG}+4000 \\
\mathrm{ppmNaCl}\end{array}$ & $25.0 f$ & $4.7 \mathrm{c}$ & $25.6 e$ & $1.7 d$ & $31.5 f$ & $5.3 d$ & $8.4 d$ & $4.37 e$ & $13.5 f$ \\
\hline $\begin{array}{c}\mathrm{UG}+6000 \\
\mathrm{ppmNaCl}\end{array}$ & $21.0 \mathrm{~g}$ & $4.1 \mathrm{c}$ & $14.6 f$ & $0.01 f$ & $26.2 \mathrm{~g}$ & $4.1 \mathrm{e}$ & $6.0 \mathrm{e}$ & $3.1 f$ & $10.6 \mathrm{~h}$ \\
\hline $\mathrm{G}+2000 p p m \mathrm{NaCl}$ & $81.1 \mathrm{a}$ & $6.0 \mathrm{ab}$ & $80.3 b$ & $3.0 \mathrm{~b}$ & $54.7 \mathrm{~b}$ & $9.5 b$ & $14.1 b$ & $7.5 b$ & $26.3 b$ \\
\hline $\mathrm{G}+4000 \mathrm{ppmNaCl}$ & $75.0 \mathrm{~b}$ & $5.3 b c$ & $76.0 \mathrm{~b}$ & $2.2 \mathrm{c}$ & $45.2 \mathrm{c}$ & $5.5 d$ & $11.4 \mathrm{c}$ & $6.4 \mathrm{c}$ & $19.6 d$ \\
\hline $\mathrm{G}+6000 \mathrm{ppmNaCl}$ & $33.8 \mathrm{e}$ & $4.6 \mathrm{c}$ & $36.0 \mathrm{~d}$ & $1.0 \mathrm{e}$ & $31.1 f$ & $5.0 \mathrm{~d}$ & $8.5 d$ & $4.3 e$ & $12.3 \mathrm{~g}$ \\
\hline LSD & 3.6 & 1.2 & 8 & 0.46 & 0.78 & 0.65 & 0.9 & 0.55 & 0.86 \\
\hline
\end{tabular}

(proline), quaternary and tertiary onium compounds (glycine betaine, dimethylsulfoniopropionate), and polyol/small sugars (mannitol, trehalose).

All these substances are highly soluble in water and acts as free radical scavengers and directly stabilize membranes and/or proteins, (Rimando and Perkins-Veazie, 2005; Wang et al 2003 and Rhodes et al 2002).

\section{Salt injury index}

Salinity induced salt injury and this effect was increased with progress in age (Tables 3 and 4). Salt injury index mean values were higher at 40 than 20 DAP. Grafting prevented this injury at 20 DAP in plants treated with $2000 \mathrm{ppm} \mathrm{NaCl}$ salinity and reduced it under the higher concentrations of $\mathrm{NaCl}$.

Salt injury index is qualitative description of morph visible symptom on plant. However, salinity stress caused nutrient unbalance. Where $\mathrm{Na} \& \mathrm{Cl}$ were dominant against $\mathrm{K}, \mathrm{Ca}, \mathrm{P}$ either on cell membrane or inside cells. Therefore, $\mathrm{NaCl}$ salinity stress could be considered as abiotic disease resulted from physiological disorder. Leaf disease severity index \% was applied under salinity stress to reveal the degree of salt sensitive and tolerant plant (El-Shraiy et al 2011). The plasma membrane is the part of the cytoplasm that first encoun- ters the salt and this may be the primary site of salt injury. Plant species and cultivars within a crop species differ greatly in their responses to salinity (Dasgan et al 2002).

Table 3. Effect of different levels of $\mathrm{NaCl}$ salinity on membrane permeability (MP), relative water content (LRWC) and salt injury index (SII) of leaves of ungrafted (UG) and grafted (G) watermelon plants at 20 days after planting

\begin{tabular}{|c|c|c|c|}
\hline Treatments & MP $\%$ & $\begin{array}{c}\text { LRWC } \\
\%\end{array}$ & SII \\
\hline $\mathrm{UG}$ & $17.0 \mathrm{e}$ & $68.4 \mathrm{c}$ & $0.0 \mathrm{f}$ \\
$\mathrm{G}$ & $16.8 \mathrm{e}$ & $77.1 \mathrm{a}$ & $0.0 \mathrm{f}$ \\
$\mathrm{UG}+2000 \mathrm{ppm} \mathrm{NaCl}$ & $30.8 \mathrm{c}$ & $60.0 \mathrm{e}$ & $15.1 \mathrm{c}$ \\
$\mathrm{UG}+4000 \mathrm{ppm} \mathrm{NaCl}$ & $38.4 \mathrm{~b}$ & $55.0 \mathrm{~g}$ & $26.5 \mathrm{~b}$ \\
$\mathrm{UG}+6000 \mathrm{ppmNaCl}$ & $41.2 \mathrm{a}$ & $50.6 \mathrm{~h}$ & $37.5 \mathrm{a}$ \\
$\mathrm{G}+2000 \mathrm{ppm} \mathrm{NaCl}$ & $23.0 \mathrm{~d}$ & $75.5 \mathrm{~b}$ & $0.0 f$ \\
$\mathrm{G}+4000 \mathrm{ppmNaCl}$ & $30.5 \mathrm{c}$ & $67.4 \mathrm{~d}$ & $6.9 \mathrm{e}$ \\
$\mathrm{G}+6000 \mathrm{ppmNaCl}$ & $38.8 \mathrm{~b}$ & $58.4 \mathrm{f}$ & $12.9 \mathrm{~d}$ \\
\hline LSD & 0.81 & 0.91 & 0.71 \\
\hline
\end{tabular}


Table 4. Effect of different levels of $\mathrm{NaCl}$ salinity on membrane permeabikility (MP), relative water content (LRWC) and salt injury index (SII) of leaves of ungrafted (UG) and grafted $(G)$ watermelon plants at 40 days after planting

\begin{tabular}{|c|c|c|c|}
\hline Treatments & MP $\%$ & LRWC $\%$ & SII \\
\hline UG & $15.1 \mathrm{f}$ & $72.3 \mathrm{~b}$ & $0.0 f$ \\
$\mathrm{G}$ & $15.3 \mathrm{f}$ & $79.7 \mathrm{a}$ & $0.0 f$ \\
$\mathrm{UG}+2000 \mathrm{ppm} \mathrm{NaCl}$ & $36.1 \mathrm{~d}$ & $71.0 \mathrm{~b}$ & $17.6 \mathrm{~d}$ \\
$\mathrm{UG}+4000 \mathrm{ppmNaCl}$ & $41.2 \mathrm{~b}$ & $57.4 \mathrm{~d}$ & $50.3 \mathrm{~b}$ \\
$\mathrm{UG}+6000 \mathrm{ppmNaCl}$ & $46.6 \mathrm{a}$ & $52.9 \mathrm{e}$ & $66.4 \mathrm{a}$ \\
$\mathrm{G}+2000 \mathrm{ppm} \mathrm{NaCl}$ & $25.3 \mathrm{e}$ & $78.1 \mathrm{a}$ & $7.5 \mathrm{e}$ \\
$\mathrm{G}+4000 \mathrm{ppmNaCl}$ & $38.6 \mathrm{c}$ & $65.0 \mathrm{c}$ & $33.1 \mathrm{c}$ \\
$\mathrm{G}+6000 \mathrm{ppmNaCl}$ & $40.9 \mathrm{~b}$ & $56.6 \mathrm{~d}$ & $49.8 \mathrm{~b}$ \\
\hline LSD & 0.78 & 2.6 & 0.92 \\
\hline
\end{tabular}

\section{CONCLUSIONS}

Grafting of watermelon onto salt tolerance rootstock Flexifort (Cucurbita maxima x C. moschata) significantly improved growth as indicated by growth parameters; root and shoot fresh and dry weights, plant height, leaf area and number of branches. Grafting improved water status under salinity condition and minimized harmful effects of salinity on membrane permeability and visual appearance of salt injury of leaves

\section{REFERENCES}

Alpaslan, M. and Gunes, A. 2001. Interactive effects of boron and salinity stress on the growth, membrane permeability and mineral composition of tomato and cucumber plants. Plant and Soil, 236 (1) , 123-128.

Cirillo, C., Rouphael, Y., Caputo, R., G. Raimondi, M. Sifola and De Pascale, S. 2016. Effects of high salinity and the exogenous application of an osmolyte on growth, photosynthesis, and mineral composition in two ornamental shrubs. The $\mathbf{J}$. of Hort. Sci. and Biotechnology, 91(1),14-22.

Cohen, S. and Naor. 2002. The effect of three rootstocks on water use, canopy conductance and hydraulic parameters of apple trees and predicting canopy from hydraulic conductance. Plant, Cell \& Environment, 25(1),17-28.

Cushman, K. 2006. Grafting techniques for watermelon. Univ. Fla. Inst. Food Agr. Sci. HS1075, 1-5.

Çürük, S., Dasgan H.Y., Mansuroğlu S., Kurt Ş., Mazmanoğlu M., Antaklı, Ö. and Tarla, G.
2009. Grafted eggplant yield, quality and growth in infested soil with Verticillium dahliae and Meloidogyne incognita. Pesquisa Agropecuária Brasileira, 44(12),1673-1681.

Dasgan H.Y., Aktas H., Abak K. and Cakmar I. 2002. Determination of screening techniques to salinity tolerance in tomatoes and investigation and investigation of genotypes response. Plant Sci., 163(4), 695-703.

Dasgan, H.Y., Balacheva, E., Yetişir, H., Yarsi, G., Altuntas, O., Akhoundnejad, Y. and Coban, A. 2015. The effectiveness of grafting to improve salt tolerance of sensitive melon when the tolerant melon is use as rootstock. Procedia Environmental Sci., 29, 268.

Davis, A.R., Perkins-Veazie, P., Sakata, Y., López-Galarza, S., Maroto, J.V., Lee, S.G., Huh, Y.C., Sun, Z., Miguel, A. and King, S.R. 2008. Cucurbit grafting. Critical Reviews in Plant Sci., 27 (1), 50-74.

El-Shraiy, A.M., Mostafa, M., Zaghlool, S.A. and Shehata, S. 2011. Physiological aspect of $\mathrm{NaCl}$-salt stress tolerant among cucurbitaceous cultivars. Australian J. of Basic and Applied Sci., 5(11), 62-71.

Elkahoui, S., Hernández, J.A., Abdelly, C., Ghrir, R. and Limam, F. 2005. Effects of salt on lipid peroxidation and antioxidant enzyme activities of Catharanthus roseus suspension cells. Plant Sci., 168(3), 607-613.

Estan, M.T., Martinez-Rodriguez, M.M., PerezAlfocea, F., Flowers, T.J. and Boların, M.C. 2005. Grafting raises the salt tolerance of tomato through limiting the transport of sodium and chloride to the shoot. J. Exp. Bot., 56, 703-712.

Gomez, K.A. and Gomez, A.A. 1984. Statistical Procedures for Agricultural Research, Ed $2^{\text {nd }}$. John Wiley and Sons, New York, pp, 20-29 and 329-387.

Jacoby, B. 1994. Mechanisms involved in salt tolerance by plants. In:Pessarakli, M. (Ed), Handbook of plant and crop stress. Marcel Dekker, New York, pp, 97-123.

Karaağaç, O. and Balkaya, A. 2013. Interspecific hybridization and hybrid seed yield of winter squash (Cucurbita maxima Duch.) and pumpkin (Cucurbita moschata Duch.) lines for rootstock breeding. Scientia Horticulturae, 149, 9-12.

Kaya, C., Higgs, D. and Kirnak, H. 2001. The effects of high salinity $(\mathrm{NaCl})$ and supplementary phosphorus and potassium on physiology and nutrition development of 
spinach. Bulg. J. Plant Physiol., 27(3-4), 4759.

Kong, L., Wang, M. and Bi, D. 2005. Selenium modulates the activities of antioxidant enzymes, osmotic homeostasis and promotes the growth of sorrel seedlings under salt stress. Plant Growth Regulation, 45,155-163.

Kusvuran, S., Ellialtioglu, S. and Polat Z. 2013. Applications of salt and drought stress on the antioxidative enzyme activities and malondialdehyde content in callus tissues of pumpkin genotypes. J. of Food Agri. and Environ., 11(2), 496-500.

Levitt, J. 1980. Responses of Plants to Environmental Stress, Volume 1: Chilling, Freezing, and High Temperature Stresses. Academic Press, 497 p.

Lee, J.M. 1994. Cultivation of grafted vegetables I: current status, grafting methods and benefits. Hort. Sci., 29, 235-239.

Lee, J.M. 2003. Advances in vegetable grafting. Chronica Hort., 43, 13-19.

Mansour, M.M.F. and Salama, K.H. 2004. Cellular basis of salinity tolerance in plants. Environmental and Experimental Botany, 52(2), 113-122.

Marschner, H. 1995. Part I. Nutritional physiology. In: Mineral Nutrition of Higher Plants. Marschner, H. $2^{\text {nd }}$. Academic Press. London, pp. 18-30.

Meloni, D.A., Oliva, M.A., Martinez, C.A. and Cambraia, J. 2003. Photosynthesis and activity of superoxide dismutase, peroxidase and glutathione reductase in cotton under salt stress. Environmental and Experimental Botany, 49(1), 69-76.

Munns R. 2002. Comparative physiology of salt and water stress, Plant Cell Environ. 25, 239-250.

Munns, R. and Termatt, A. 1986. Whole plant responses to salinity. Aust. J. Plant Physiol. 13, 143-160.

Munns R. and Tester, M. 2008. Mechanisms of salinity tolerance. Annu . Rev .Plant Biol. 59, 651-681.

Munns, R. and Gilliham, M. 2015. Salinity tolerance of crops-what is the cost? New Phytologist, 208(3), 668-673.

Oda, M. 1995. New grafting methods for fruitbearing vegetables in Japan. JARQ (Japan),

Ors, S. and Suarez, D. 2016. Salt tolerance of spinach as related to seasonal climate. Hort. Sci., (Prague), 43, 33-41.
Parvaiz, A. and Satyawati, S. 2008. Salt stress and phyto-biochemical responses of plants-a review. Plant Soil and Environment, 54(3), 89.

Rhodes, D., Nadolska-Orczyk, A. and Rich, P. 2002. Salinity, osmolytes and compatible solutes. In Salinity: Environment-PlantsMolecules. Springer, pp. 181-204.

Rimando, A.M. and Perkins-Veazi,e P.M. 2005. Determination of citrulline in watermelon rind. J. of Chromatography A, 1078(1), 196-200.

Rouphael, Y., Mouneimne, A., Rivera, C.M., Cardarelli, M., Marucci A. and Colla, G. 2010. Allometric models for non-destructive leaf area estimation in grafted and ungrafted watermelon (Citrullus lanatus Thunb.) J. Food, Agric. \& Environment, 8(1), 161-165.

Ruiz, J.M., Belakbir, A., Lhpez-Cantarero, I. and Romero, L. 1997. Leaf-macronutrient content and yield in grafted melon plants. A model to evaluate the influence of rootstock genotype. Sci. Hortic. 71, 227-234.

Sevengor, S., Yasar, F., Kusvuran, S. and Ellialtioglu, S. 2011. The effect of salt stress on growth, chlorophyll content, lipid peroxidation and antioxidative enzymes of pumpkin seedling. African $J$. of Agric. Research, 6(21), 4920-4924.

Shi, Q., Bao, Z., Zhu, Z., Ying, Q. and Qian Q. 2006. Effects of different treatments of salicylic acid on heat tolerance, chlorophyll fluorescence, and antioxidant enzyme activity in seedlings of Cucumis sativa L. Plant Growth Regulation, 48,127-135

Silveira, J.A.G., de Almeida Viégas, R., da Rocha, I.M.A., Moreira, A.C.D.O.M., de Azevedo Moreira R. and Oliveira J.T.A. 2003. Proline accumulation and glutamine synthetase activity are increased by salt-induced proteolysis in cashew leaves. J. of Plant Physiology, 160(2), 115-123.

Sudhakar, C., Lakshmi, A. and Giridarakumar S. 2001. Changes in the antioxidant enzyme efficacy in two high yielding genotypes of mulberry (Morus alba L.) under $\mathrm{NaCl}$ salinity. Plant Sci,, 161(3), 613-619.

Wang, W., Vinocur, B. and Altman, A. 2003. Plant responses to drought, salinity and extreme temperatures: towards genetic engineering for stress tolerance. Planta, 218(1), 1-14.

Yeo, A.R., Capron, S.J.M. and Flowers, T.J. 1985. The effect of salinity upon photosynthesis in rice (Oryza sativa L.): gas exchange by 
individual leaves relation to their salt content. J. Exp.Bot., 36, 1240-1248.

Yetisir, H. and Uygur V. 2010. Responses of grafted watermelon onto different gourd species to salinity stress. J. of Plant Nutrition, 33(3), 315-327.

Zhang,Y.Q., Liu, S.Q., Yang, F.J. and Li, D.F. 2003. Study on screening of sal-tolerant watermelon stock and mechanism of salt- tolerance. Acta. Agric. Boreali-occidentalis Sin., 12,105-108.

Zhu, J.K. 2001. Plant salt tolerance. Trends Plant Sci., 6, 66-71.

Zhu, J.; Z. Bie and Y. Li. 2008. Physiological and growth responses of two different salt-sensitive cucumber cultivars to $\mathrm{NaCl}$ stress. Soil Sci., and Plant Nutrition, 54(3), 400-407. 